\title{
EFFICIENT AND UNBIASED TOOLS FOR QUANTITATING LEYDIG AND SERTOLI CELLS IN THE TESTIS FROM TESTES BIOPSIES
}

\author{
Peter MEIDAhl PETERSEN ${ }^{1,2}$, AleKSANDER GIWERCMAN ${ }^{1}$, HANS JøRGEN Gundersen ${ }^{3}$ AND \\ BENTE PAKKENBERG ${ }^{2}$ \\ ${ }^{1}$ Department of Growth and Reproduction, Copenhagen University Hospital, Rigshospitalet, 2100 Copenhagen $\emptyset$, \\ ${ }^{2}$ Neurological Research Laboratory, Bartholin Institute, Kommunehospitalet, Øster Farimagsgade 5, 1399 \\ Copenhagen K, ${ }^{3}$ Stereological Research Laboratory, Aarhus University, 8000 Århus C, Denmark \\ (Accepted April 19, 2000)
}

\begin{abstract}
The possibility of obtaining reliable estimates of the total number of Sertoli and Leydig cells from biopsies by use of the optical fractionator method was tested. The total number of Sertoli and Leydig cells was $522 \times 10^{6}(\mathrm{CV}=0.27)$ and $89 \times 10^{6}(\mathrm{CV}=0.34)$, respectively, when sampling in the entire testis while the

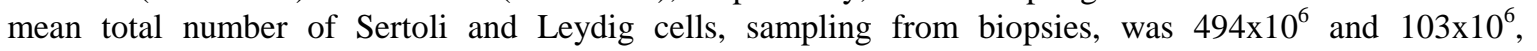
respectively, statistically a non-significant difference. The present study indicated that total number of testicular cells can be estimated stereologically from the number of cells in biopsies if the sizes of testis and the biopsy can be assessed with adequate precision.
\end{abstract}

Keywords: Leydig cells, Sertoli cells, stereology, testicular biopsy.

\section{INTRODUCTION}

Changes in numbers and/or volumes of the different cell types in the testis have been widely used endpoints in studies of testicular physiology and toxicology. However, careful analyses of the methods used in the quantitative studies are needed before the conclusions of these investigations should be accepted. Most often quantification in the testis has been carried out by profile counting in semi-thin sections, measurement of relative areas, or 2-D-ratios of the profiles studied. Based on assumptions about shape and/ or size of the cells, various methods of mathematical correction formulas have been applied to correct for these biases in conventional profile counting designs (Coggeshall and Lekan, 1996; Wreford, 1995). Animal studies comparing quantification by assumption based methods with stereological methods without assumptions of shape or shrinkage of the quantified structures have shown that conventional counting methods may severely bias the results in unpredictable ways (e.g. the results were influenced by different tissue shrinkage in hormone treated rats and control rats) (Mendis-Handagama and Ewing, 1990; Mendis-Handagama, 1992). The optical fractionator has proven to be a highly efficient stereological method for estimating the total number of cells in any organ (Gundersen et al., 1988; Petersen et al., 1996; West et al., 1991). The principal advantages of these methods include: 1) The sampling is uniform to ensure that all objects in the testis have the same probability of being sampled (e.g. all cells in the testis have one and the same chance of being sampled. 2) No assumptions about shape, size or orientation of the cells or shrinkage of the organ during histological processing are required.

The aim of the study was to clarify whether biopsies can be used to estimate total cell numbers in the human testis.

\section{MATERIAL}

One testis was sampled from each of 9 males who due to sudden, unexpected death had been taken to the Department of Forensic Medicine in Copenhagen. Systematic sampling with a random start was used to estimate the total number of Sertoli and Leydig cells in these testes. Moreover, one biopsy from each of the same 9 testes was used to estimate the total number of Leydig and Sertoli cells in testicular biopsies from the same individuals. 


\section{METHODS}

\section{ESTIMATION OF TOTAL SERTOLI AND LEYDIG CELL NUMBER IN INTACT HUMAN TESTES}

1) The entire testis was fixed in a fixative containing $20 \mathrm{ml}$ formaldehyde $40 \%$ and $4 \mathrm{ml}$ acetic acid and $76 \mathrm{ml}$ water. From each testis, a known fraction of the tissue was sampled systematically with a random start in a careful stepwise sampling procedure: a) Each testis was cut into 4-mm-thick slabs, providing 8-12 slabs; b) Every $2^{\text {nd }}-3^{\text {rd }}$ slab was sampled systematically randomly and cut into 4-mm-thick bars providing 6-10 bars; c) every $2^{\text {nd }}-3^{\text {rd }}$ bar was sampled and cut into cubes; d) every $4^{\text {th }}$ to $6^{\text {th }}$ of these cubes (approximately 8-10 cubes) were sampled.

2) The sampled tissue was embedded in 2-hydroxymethacrylate (Technovit $7100 ®$ ) and stained with hematoxylin eosin where the Leydig cells and Sertoli cells can be recognised.

3) The blocks of methacrylate, each containing 8-10 cubes of testicular tissue, were cut into $40-\mu \mathrm{m}$ thick sections.

4) Approximately 10 sections were sampled from each testis and the optical fractionator principle used to estimate the total number of Sertoli and Leydig cells in a known fraction of the tissue. To avoid bias from cutting artefacts a disector height of $15 \mu \mathrm{m}$ was chosen. By this sampling procedure the coefficient of error $(\mathrm{CE}=\mathrm{SEM} /$ mean $)$ at each sampling level is estimated and kept below $10 \%$.

5) Approximately 150 of each cell type in each testis was counted. The Sertoli cells were recognised in the seminifereous tubules by their pale invaginated irregular nuclei with a prominent nucleolus. The Leydig cells were recognised in the interstitium as relatively large ovoid shaped cell with an eccentric nucleus. The nucleus contained a prominent nucleolus and peripherally localised chromatin. To obtain approximately the same sample size different sampling frame sizes were used for Sertoli and Leydig cells. The frame size for Sertoli cells were approximately $600 \mu \mathrm{m}^{2}$ and for Leydig cells $2700 \mu \mathrm{m}^{2}$.

6) The total number of Sertoli and Leydig cells were estimated by multiplication of the counted number of cells $(\Sigma \mathrm{Q})$ by the inverse of the sampled fraction. For example in one testis every $2^{\text {nd }}$ slab, every $3^{\text {rd }}$ bar, every $6^{\text {th }}$ cube, and every $12^{\text {th }}$ methacrylate section were sampled and counting of Leydig cells was performed in 1/367 of the sampled tissue section. Thus the global sampling fraction was 1 : $(2 \times 3 \times 6 \times 12 \times 367)$ and the total number of Leydig cells was the inverse sampling fraction multiplicated with $\Sigma$ Q.

\section{ESTIMATION OF TOTAL SERTOLI AND LEYDIG CELL NUMBER IN HUMAN TESTES FROM BIOPSIES}

As in clinical practice the biopsies were taken as wedge biopsies at the anterior surface of the testes. The biopsies were taken after the testes were removed from the body. Both testicular size and biopsy size were measured by weight after fixation. The sizes of the biopsies ranged from 20-200 mg. The biopsies were embedded in 2-hydroxy-methacrylate (Technovit $7100^{\circledR}$ ). Each block of methacrylate embedded biopsy was cut exhaustively into $40-\mu \mathrm{m}$-thick sections. Approximately 10 sections were sampled from each biopsy and stained with hematoxylin eosin. As above mentioned a disector height of 15- $\mathrm{m}$ was chosen. The sampling fraction was chosen so that approximately 150 of each cell type were counted in each biopsy. The total number of Sertoli and Leydig cells in the biopsy was estimated by multiplication of the counted number of cells by the inverse of the sampled fraction, e.g. in one testis the biopsy was $1 / 131$ of the entire testis, every $6^{\text {th }}$ methacrylate section was sampled and counting of Leydig cells was performed in 1/1584 of the tissue section. The estimated number of Leydig cells in the testis was equal to: $131 \times 6 \times 1584 x$ the counted number of Leydig cells ( $\Sigma \mathrm{Q})$.

To evaluate the results obtained by biopsies, we compared the estimates of total Sertoli and Leydig cell number obtained by sampling from the entire testis to the estimates obtained by sampling from a biopsy of the same testes. The data were analysed using a two-tailed paired t-test. In four cases the number of cells estimated from two different biopsies from the same testis were also compared. The mean values and coefficient of variation $(\mathrm{CV}=\mathrm{SD} /$ mean given in parentheses) between testes were calculated for each cell type. Correlation between number of Sertoli and Leydig obtained from sampling in the entire testis and from a biopsy of the testis was assessed by calculation of Pearson correlation coefficient. 


\section{RESULTS}

Using the entire testis the mean total number of Sertoli cells in the testes was $522 \times 10^{6}(0.27)$ and $\mathrm{CE}=0.09$ (Fig. 1). The mean total number of Leydig cells was $89 \times 10^{6}(0.34)$ and $\mathrm{CE}=0.09$ (Fig. 1). The $\mathrm{CV}$ at the sampling level of cubes was 0.04 for Sertoli cells and 0.22 for Leydig cells.

Using the biopsies, the estimated mean total number of Sertoli cells in the testes was $494 \times 10^{6}$ $(0.28)$ and the estimated mean total number of Leydig cells $103 \times 10^{6}(0.59)$ (Table 1). The number of counted Sertoli and Leydig cells in the biopsies was 94-177 and 72-206, respectively.
Analyses of the differences of Sertoli cell and Leydig cell numbers obtained from sampling in the entire testis and from a biopsy, respectively, did not show any statistically significant differences (paired t-test: $\mathrm{p}=0.50$ and $\mathrm{p}=0.43$, respectively) (Table 1 ). Comparison of total numbers of Sertoli and Leydig cells estimated from two different biopsies from the same testis is shown in Table 2. Addition of one more biopsy in the sampling procedure had only a low impact on the $\mathrm{CE}$ of the estimates of total numbers of Sertoli and Leydig cells compared with the high biological variation. In these few individuals correlation was observed between number of Sertoli and Leydig cells obtained from sampling in the entire testis and from a biopsy respectively $(\mathrm{p}=0.07$ and 0.09$)$.

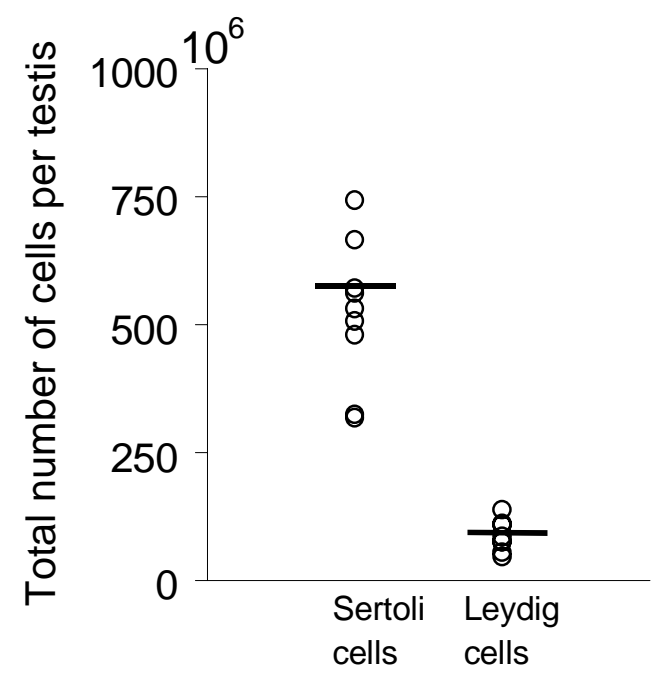

Fig. 1. Estimation of Sertoli and Leydig cell number in human testes. --: Mean values.

Table 1. Total number of Sertoli and Leydig cells estimated from a biopsy and from the entire testis

\begin{tabular}{lllll}
\hline & Sertoli cells $\left(10^{6}\right)$ & \multicolumn{3}{l}{ Leydig cells $\left(10^{6}\right)$} \\
\cline { 2 - 5 } & Biopsy & Entire testis & Biopsy & Entire testis \\
\hline 323 & 324 & 44 & 55 \\
& 452 & 665 & 60 & 47 \\
438 & 561 & 126 & 86 \\
& 663 & 743 & 87 & 109 \\
& 318 & 48 & 111 \\
& 599 & 480 & 242 & 138 \\
& 477 & 571 & 90 & 75 \\
& 676 & 507 & 134 & 75 \\
Mean $(\mathrm{CV})$ & 531 & 531 & 95 & 108 \\
\hline
\end{tabular}


Table 2. Total number of Sertoli and Leydig cells estimated from two different biopsies from the same testis

\begin{tabular}{lllllll}
\hline & \multicolumn{5}{l}{ Sertoli cells $\left(10^{6}\right)$} & \multicolumn{4}{l}{ Leydig cells $\left(10^{6}\right)$} \\
\cline { 2 - 7 } & Biopsy 1 & Biopsy 2 & Biopsy $1+2$ & Biopsy 1 & Biopsy 2 & Biopsy 1+2 \\
\hline$\# 1$ & 323 & 397 & 360 & 44 & 43 & 44 \\
$\# 2$ & 452 & 494 & 473 & 60 & 62 & 61 \\
$\# 3$ & 438 & 651 & 545 & 126 & 127 & 127 \\
$\# 4$ & 663 & 637 & 650 & 87 & 113 & 100 \\
\hline Mean(CV) & $469(0.26)$ & $545(0.19)$ & $507(0.21)$ & $79(0.39)$ & $86(0.40)$ & $83(0.39)$ \\
\hline
\end{tabular}

\section{DISCUSSION}

The mean number of Sertoli cells in testes from adult males is approximately $500 \times 10^{6}$ and the number of Leydig cells approximately $100 \times 10^{6}$. The total Leydig and Sertoli cell numbers, estimated by use of stereological methods, differed from the results obtained from most previous studies. The estimated total Sertoli cell numbers have been reported to range from 390 to $3700 \times 10^{6}$ and the total Leydig cell number from 400 to $800 \times 10^{6}$, calculated from twodimensional profile counting (Cortes et al., 1987; Paniagua et al., 1987; Kaler and Neaves, 1978; Neaves et al., 1985). These large ranges may be ascribed to the difficulties in interpretation of results obtained from assumption based designs as previously described (Mendis-Handagama and Ewing, 1990; Mendis-Handagama, 1992). At the scale of the $4 \times 4 \times 4$ $\mathrm{mm}^{3}$ cubes, the Leydig cells showed a more pronounced heterogenecity in the testis than Sertoli cells. The imprecision in the estimation of Leydig cells in the biopsy will therefore be higher than the one of Sertoli cells due to testis inhomogenicity of Leydig cells compared with Sertoli cells. This observation implies a limit for the precision of the estimates of Leydig cells due to the limitation given in the size of the biopsy $(20-200 \mathrm{mg})$. The imprecision of the estimates of Sertoli and Leydig cells obtained from a biopsy should be seen in the view of the very large biological variation observed when the total number of cells was estimated by use of a proper optical fractionator design (Table 1). The very large biological variation implies that even the relatively large imprecision of estimates obtained from biopsies will be acceptable in most clinical situations and that the most important factor in clinical studies comparing groups of patients will be the number of individuals included. One can therefore not recommend that patients should be exposed to more than one biopsy because each biopsy is highly unpleasant to the patient (Bruun et al., 1987). The size of a biopsy is difficult to obtain in practice because the routine biopsies are very small (20$200 \mathrm{mg}$ ). Ultra-sonography has proven to be very precise in assessment of testicular size in comparison with testicular volume determined by water replacement and weight (Lenz et al., 1993).

The present results indicate that useful information can be obtained about human testis by stereological investigation of biopsies in different groups of patients. Being able to quantitate the total number of the different testicular cells from a testis biopsy, correlations between quantitative findings, physiological markers and clinical outcome may add important knowledge about testicular function and pathophysiology of various diseases to the current knowledge of the human testis.

We have described the estimation of total number as an example of the use of stereological methods. In this design using methacrylate embedding other parameters such as mean cell volumes and surface areas of cells or length of structures can also be quantitated stereologically (Gundersen et al., 1988). Because the sample design of estimations of total cell numbers eliminates requirements of assumptions about shrinkage other methods of embedding could be used as well. The only requirement is that the cells can be recognised and distinguished.

In conclusion, total number of testicular cells can be estimated stereologically from the number of cells in biopsies if the size of testis and biopsy can be assessed with adequate precision.

\section{ACKNOWLEDGEMENT}

The economic support given by The Hartmann Foundation, Direktør Emil Hertz and wife Inger Hertz Foundation, and Fabrikant Einar Willumsens Mindelegat is highly appreciated. 


\section{REFERENCES}

Bruun E, Frimodt-Møller C, Giwercman A, Lenz S, Skakkebæk NE (1987). Biopsy as an outpatient procedure in screening for carcinoma-in-situ: complications and the patient's acceptance. Int $\mathbf{J}$ Androl 10:199-202.

Coggeshall RE, Lekan HA (1996). Methods for determinating numbers of cells and synapses: A case for more uniform standards of review. J Comp Neurol 364:6-15.

Cortes D, Müller J, Skakkebæk NE (1987). Proliferation of Sertoli cells during development of the human testis assessed by stereological methods. Int $\mathrm{J}$ Androl 10:589-96.

Gundersen HJ, Bagger P, Bendtsen TF et al (1988). The new stereological tools: disector, fractionator, nucleator and point sampled intersepts and their use in pathological research and diagnosis. APMIS 96:85781.

Kaler LW, Neaves WB (1978). Attrition of the human Leydig cell population with advancing age. Anat Rec 192:513-8.

Lenz S, Giwercman A, Elsborg A, Cohr K-H, Jelnes JE (1993). Ultrasonic testicular texture and size in 444 men from the general population: correlation to semen quality. Eur Urol 24:231-8.
Mendis-Handagama SMLC, Ewing LL (1990). Sources of error in the estimation of Leydig cell numbers in control and atrophied mammalian testes. $\mathrm{J}$ Micros 159:73-82.

Mendis-Handagama SMLC (1992). Estimation error of Leydig cell numbers in atrophied rat testes due to the assumption of spherical nuclei. J Micros 168:25-32.

Neaves WB, Johnson L, Petty CS (1985). Age-related change in numbers of other interstitial cells in testis of adult men: Evidence bearing on the fate of Leydig cells lost with increasing age. Biol Reprod 33:259-69.

Paniagua R, Martín A, Nistal M, Amat P (1987). Testicular involution in elderly men: comparison of histologic quantitative studies with hormone patterns. Fertil Steril 47:671-9.

Petersen PM, Pakkenberg B, Giwercman A (1996). The human testis studied using stereological methods. Acta Stereol 15:181-5.

West M, Slomianka L, Gundersen HJG (1991). Unbiased stereological estimation of the total number of neurons in the subdivisions of the rat hippocampus using the optical fractionator. Anat Rec 231:482-97.

Wreford NG (1995). Theory and practice of stereological techniques applied to the estimation of cell number and nuclear volume in the testis. Microsc Res Tech 32:42336. 